\title{
DESIGN AND OPERATING ASSESSMENT OF SOLAR PV UNDERGROUND WATER PUMPING SYSTEM IN UPPER EGYPT
}

\author{
Abd Allah W. E* and Tawfik M.A.*
}

\begin{abstract}
This work presents a detailed approach to the optimum design, performance and economical assessment of a solar PV underground water pumping system using AC submersible pump and motor based on the proposed daily water demands for a farm allocated in remote area in Upper Egypt under the least solar radiation conditions during the winter season. The performance assessment after the PV pumping system installation was performed taking into consideration the insolation period, water flow rate, hydraulic power, PV electric output power, pump and pumping system efficiencies. The assessment results indicated that the insolation period extended to 6 hours from 9:00 to 15:00 where the $P V$ current affected strongly by the variation of the solar radiation intensity and consequently the motor speed, while the voltage remained stable. The data revealed that the solar radiation has high correlation $\left(R^{2}=0.9618\right)$ with water flow rate due to the continuous changes in the current where the PV system gave average daily flow rate of $49.50 \mathrm{~m}^{3} / \mathrm{h}$ that higher than the design flow rate of $48 \mathrm{~m}^{3} / \mathrm{h}$. Moreover, maximum hydraulic pump power was $7518.40 \mathrm{~W}$ (at noon) which is higher than the designed hydraulic power of $7394.5 \mathrm{~W}$ and this means that the pump efficiency was exceed the suggested efficiency of $75 \%$ during designing of the PV system. Generally, the average pump and PV pumping system efficiencies were 64.8 and $13.10 \%$, respectively. High validation was proved through the assessment with the design aspects of the PV pumping system and good performance of the selected pump, motor and PV configuration. Ultimately, the $P V$ pumping system was saved the annualized and pumping costs with 47.33 and $36.36 \%$, respectively, comparing to the diesel-pumping system at the same well.
\end{abstract}

Keywords: Design, Solar PV, Pumping system, Remote area, Performance assessment, Pumping cost

\footnotetext{
*Agricultural Engineering Dept., Fac. of Agric., Zagazig Univ., Egypt.
} 


\section{INTRODUCTION}

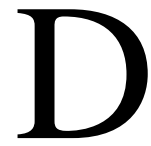
ue to the rapid accretion of population all over the world and the lack of the fresh water resources availability, the problem of fresh water shortage will be emerged and aggravated by the increase of the fresh and potable water demands. The arid and semi-arid regions are almost suffering of rarely rainfall and even sometimes the deficiency of surface water sources existing, whilst the water transportation to these areas is considered uneconomical and unreliable option. Simultaneously, the adequate water for people needs or for irrigation is one of the most crucial factors that can play a vital role in the stability of rural life (Ba et al., 2018). The majority of the commercially available irrigation water pumps are powered by electricity or diesel oil (Aliyu et al., 2018). In the same context, remote and isolated communities have limit or no connection to the national electricity grid (Meah et al., 2008) that can lead to full the dependence on utilizing the ground water for domestic uses in farms using fossil fuels based pumping systems. The tough disadvantages of using diesel- powered pumps represent in price and transportation cost, in addition to the adverse and negative impact on the environment (Santra $\boldsymbol{e t}$ al., 2016). One of the most potential renewable energy is the solar energy as an abundant, green and sustainable source (Tawfik, 2018). The technology of solar-powered water pumping becomes very essential to conserve valuable resources like water and energy (Korpale et al., 2016). Solar pumps are particularity useful for intermediate applications like small villages and moderate agricultural needs (Benghanem et al., 2013). Nowadays, solar photovoltaic (PV) water pumping systems one of the most critical solutions to provide access to water in areas suffering of absence of electricity (Li et al., 2017) and can be a potential option than conventional pumps to draw down water in developing countries (Tiwari and Kalamkar, 2018). During the few past years, various studies were concentrated on photovoltaic water pumping system (PVWPS) sizing, according to the potential of solar energy and water demands (Munir et al., 2007). Sizing and the efficiency of the PV pumping system are mainly based on the effect of intensity of solar radiation (Ghoneim, 2006). Hamidat and Benyoucef (2009) reported that PV pumping system performance strongly depends on PV array peak power and total head. Due to its brilliant location in the sun- 
belt zone, Egypt is being among the most sunlight-sufficient places on the globe with annual 2,400 hours of solar operation annually with high intensity of direct solar radiation equivalent to $2,000-2,600 \mathrm{kWh} / \mathrm{m}^{2}$ (REVE, 2013).Thus, a large potential of using the PV water pumping system in Egypt on the level of economic and performance especially in the remote-desert sites that have high solar radiation intensity and destitute of electricity in attempts to create new communities and dwellings. The performance of PV water pumping system is prospective at remote areas in Upper Egypt which has the advantage of relative high solar radiation in event of cloudy weather in winter season to insure of delivering the adequate amount of water to meet the farm/or dwelling needs for drinking and irrigation, particularly the sites with non-deep underground water surface. This paper presents a detailed approach to the optimum design, configuration, performance and economical assessment of a solar PV water pumping system based on the proposed water demands of a farm in remote-desert area in Upper Egypt under the least solar radiation conditions during the winter season.

\section{MATERIALS AND METHODS}

This work presents design, operation assessment and cost analysis of solar PV pumping system serving a local farm with area allocated in remotedesert site in Eastern Nile region belonged to Qena Governorate (Lat. $26^{\circ}$ $10^{\prime} \mathrm{N}$, Long. $32^{\circ} 43^{\prime} \mathrm{E}$ ), Upper of Egypt (UoE). This investigation aims to install the optimum size of the solar-powered pumping system that meets the water demands of the farm at remote area under the lowest solar radiation intensity conditions during the winter season at this location in Egypt. Afterwards, performance of the installed solar pumping system was tested under the real climatic conditions during five consecutive days extended from 18 to 23 of January 2019 to realize the relation between the system sizing and its actual performance in addition to cost analysis based on the life cycle costs (LCC) method to determine the cost per volumetric unit of the solar pumping water comparing to the cost per volumetric unit of the water using diesel- water pump.

\section{A- Design of solar PV pumping system}

The design (sizing) procedure of the proposed solar PV pumping system was performed throughout the following steps: 


\section{1-Determine the overall water requirement in farm}

The overall water requirement can be determined by the daily water consumption for human, livestock and irrigation in the farm reach about $288 \mathrm{~m}^{3}$ according to Table (1).

Table(1): Farm's daily water requirement

\begin{tabular}{|c|c|c|}
\hline Human/livestock/ irrigation & $\begin{array}{l}\text { Approx. average water } \\
\text { requirement, } \mathrm{m}^{3} / \mathrm{day}^{*}\end{array}$ & $\begin{array}{l}\text { Total daily water } \\
\text { consumption, } \mathbf{m}^{3}\end{array}$ \\
\hline 10 persons & $150 \mathrm{~L} /$ person* & 1.5 \\
\hline $\begin{array}{l}5 \text { Holstein dairy cows }(13.6-22 \mathrm{~kg} \\
\text { milk/day) }\end{array}$ & $\begin{array}{l}115 \mathrm{~L} / \mathrm{cow} \text { (Av.750 kg } \\
\text { weight) } * *\end{array}$ & 0.5750 \\
\hline 2 Dry cows & $41 \mathrm{~L} / \mathrm{cow}^{* *}$ & 0.0820 \\
\hline $\begin{array}{l}3 \text { calves (1-4 months) and } 2 \text { heifers } \\
\text { (5-24 months) }\end{array}$ & $\begin{array}{l}9 \mathrm{~L} / \text { dairy calf- } 25 \mathrm{~L} / \mathrm{calf} \\
\text { heifer** }\end{array}$ & 0.0770 \\
\hline 1 Beef cattle (Bull) & $38 \mathrm{~L} / \mathrm{Bull} * *$ & 0.0380 \\
\hline 20sheep (lamb+meat+lactating ewe) & $6.68 \mathrm{~L} /$ sheep $^{* *}$ & 0.0134 \\
\hline 100 egg-chickens & $320 \mathrm{~L} / 1000$ bird $* *$ & 0.0320 \\
\hline 100 meat-chickens (Broiler) & $660 \mathrm{~L} / 1000$ bird at $32^{\circ} \mathrm{C} * *$ & 0.0660 \\
\hline Irrigation & Crop, seedlings ,trees ...etc. & 285.616 \\
\hline \multicolumn{2}{|c|}{ The overall daily water requirement within farm } & 288 \\
\hline
\end{tabular}

*According to World Health Organization (WHO, 2018)

** Ward and McKague (2007)

\section{2- Water source and location}

The water source will depend on artesian well located at $70 \mathrm{~m}$ away from the farm site with underground water depth of $23 \mathrm{~m}$, but the proposed intake point was $30 \mathrm{~m}$ beneath the ground level

\section{3- The solar pumping system component}

The proposed system will be comprised from AC submersible pump due to its long life span, high speed and power (Aliyu et al., 2018), PV array, submersible pump motor, motor driver, water reservoir and PVC pipe and its fittings.

\section{4-Estimating the hydraulic power of the pump}

The hydraulic power of the required pump (Watt) can be calculated as follows:

$$
P_{H}=\frac{\rho g Q_{D} H_{D}}{3600}
$$

where the $\rho$ is water density $\left(1000 \mathrm{~kg} / \mathrm{m}^{3}\right), g$ is the gravitational acceleration $\left(9.81 \mathrm{~m} / \mathrm{s}^{2}\right), Q_{D}$ is the design flow rate $\left(\mathrm{m}^{3} / \mathrm{h}\right)$ and $H_{D}$ is the total dynamic head $(\mathrm{m})$. 
The design flow rate can be estimated by dividing the total water requirement within the farm by average sunny hours (according to the location and climatic condition, the peak energy hours was taken 6 h) as follows:

$$
\mathrm{Q}_{\mathrm{D}}=\frac{\text { Overall water requirement in farm }\left(\mathrm{m}^{3} /\right. \text { day) }}{\text { Averagenumber of sunny hours / day }}
$$

The total dynamic head can be calculated by the relation below:

$$
H_{D}=H_{s t s}+H_{f}
$$

where the $H_{s t s}$ is the total static head or the vertical distance between the water intake point in well and discharge point (m) and $H_{f}$ is the total head losses $(\mathrm{m})$, while the drawdown of well water was neglected.

The total head losses comprised of the main losses due to the friction $H_{f 1}$ (m) and the minor losses due to the pipe's fittings $H f 2(\mathrm{~m})$ such as; elbow, valves ...etc. It can be expressed

$$
H_{f}=H_{f 1}+H_{f 2}
$$

The friction losses $\left(H_{f l}\right)$ can be calculated by the following equation

$$
\begin{gathered}
\mathrm{H}_{\mathrm{f} 1}=\lambda \frac{L}{D} \frac{V^{2}}{2 g} \\
\mathrm{H}_{\mathrm{f} 2}=k \frac{V^{2}}{2 g}
\end{gathered}
$$

where the $\lambda$ is the friction coefficient, $L$ the total length of the pipe (m), $D$ is the pipeline diameter $(\mathrm{m}), V$ is the water velocity $\left(\mathrm{Q} / \pi \mathrm{r}^{2}\right)$ in $\mathrm{m} / \mathrm{s}, g$ is the gravitational acceleration $\left(\mathrm{m} / \mathrm{s}^{2}\right)$ and $k$ is the minor loss coefficient. The friction coefficient $(\lambda)$ can be estimated by determining the Reynolds number $(R e)$ as follows:

$$
\operatorname{Re}=\frac{\rho V D}{\mu}
$$

where the $\rho$ is water density $\left(\mathrm{kg} / \mathrm{m}^{3}\right), V$ is the water velocity $(\mathrm{m} / \mathrm{s}), D$ is the pipeline diameter $(\mathrm{m})$ and $\mu$ is the dynamic absolute viscosity $\left(\mathrm{Ns} / \mathrm{m}^{2}\right)$. The turbulent flow is expected (For turbulent when $R e>4000$ ), hence the friction coefficient $(\lambda)$ can be calculated by the formula given by Zigrang and Sylvester (1982) as follows: 


$$
\frac{1}{\sqrt{\lambda}}=-2 \log _{10}\left[\frac{\varepsilon}{3.7 \mathrm{D}}-\frac{5.02}{\mathrm{Re}} \log _{10}\left(\frac{\varepsilon}{3.7 D}+\frac{13}{\mathrm{Re}}\right)\right]
$$

where the $\varepsilon$ is the absolute roughness coefficient.

\section{5-The pump efficiency $\left(\eta_{p}\right)$}

The pump efficiency can be defined as the ratio of the hydraulic power of the pump $\left(P_{H}\right)$ to the output electrical power $\left(P_{E}\right)$ generated by the PV arrays as follows:

$$
\eta_{\mathrm{p}}=\frac{P_{H}}{P_{E}}=\frac{P_{H}}{I_{m} \times V_{m}} \times 100
$$

where the $I_{m}$ is the measured current (A) and $V_{m}$ is the measured voltage (V).

\section{6-The solar pumping system efficiency $\left(\eta_{s}\right)$}

It can be defined as the ratio of the hydraulic power of the pump $\left(P_{H}\right)$ to the total power of incident solar radiation $\left(P_{S}\right)$ onto the PV arrays as follows:

$$
\eta_{S}=\frac{P_{H}}{P_{S}}=\frac{P_{H}}{I_{S} \times A_{P V}} \times 100
$$

Where the $I_{S}$ is the total incident solar radiation $\left(\mathrm{W} / \mathrm{m}^{2}\right)$ and $A_{P V}$ is the total area of the PV arrays $\left(\mathrm{m}^{2}\right)$.

\section{According to the previous:}

1- The overall daily amount of the required water was $288 \mathrm{~m}^{3}$; hence a rectangular concrete reservoir was constructed with dimensions of $12 \times 12 \times 2.25 \mathrm{~m}$ (Width $\times$ Length $\times$ Depth) as water reservoir (the water depth is $2 \mathrm{~m}$ within the reservoir to make the store volume $288 \mathrm{~m}^{3}$ ).

2- The design flow rate $\left(Q_{D}\right)$ was estimated to be $48 \mathrm{~m}^{3} / \mathrm{h}$.

3- The total dynamic head $\left(\mathrm{H}_{\mathrm{D}}\right)$ was estimated to be $42.40 \mathrm{~m}$, based on the depicted data in Table (2).

4- Based on the design data, the hydraulic power of the required pump $\left(P_{H}\right)$ was determined to be $5545.90 \mathrm{~W}$

5- The commercial pump almost with efficiency around of $75 \%$, hence the calculated required power for the proposed pump will be $7394.5 \mathrm{~W}$. Accordingly, the pump was selected with rated power of $7.50 \mathrm{~kW}(10$ hp) with a compatible submersible motor. The specifications of the selected pump and motor are depicted in Table (3). 
Table (2): Data concerning with the total dynamic head of the pumping system

\begin{tabular}{|l|l|}
\hline Intake point depth from ground level & $30.00 \mathrm{~m}$ \\
\hline Height of discharge point above ground & $1.250 \mathrm{~m}$ \\
\hline The total static head & $31.250 \mathrm{~m}$ \\
\hline Pipeline from pump to the water reservoir & Rigid PVC \\
\hline Pipeline Length & $104.250 \mathrm{~m}$ \\
\hline Pipeline diameter & $0.1016(4$ inches $)$ \\
\hline Average water velocity at $\mathrm{Q}_{\mathrm{D}}=48 \mathrm{~m}^{3} / \mathrm{h}$ & $1.645 \mathrm{~m} / \mathrm{s}$ \\
\hline Plastic elbow, Flanged Regular $90^{\circ}$ & 6 pieces \\
\hline Minor losses coefficient $(k)$ & $0.30^{*}$ \\
\hline Minor losses along pipeline $\left(h_{f 2}\right)$ & $0.248 \mathrm{~m}$ \\
\hline Dynamic absolute viscosity $(\mu)$ for water & $0.001 \mathrm{Ns} / \mathrm{m}^{2}\left(\text { at } 20^{\circ} \mathrm{C}\right)^{*}$ \\
\hline The Avg. absolute roughness of pipeline $(\varepsilon)$ & $0.004 \mathrm{~mm} *$ \\
\hline Reynolds number $(R e)$ & $167132($ Turbulent flow $)$ \\
\hline Friction coefficient $(\lambda)$ & $0.077^{*}$ \\
\hline Friction losses $\left(h_{f 1}\right)$ & $10.90 \mathrm{~m}$ \\
\hline
\end{tabular}

* www.engineeringtoolbox.Com

Table (3):The specifications of the selected pump and motor

\begin{tabular}{|l|l|}
\hline \multicolumn{1}{|c|}{ Pump } & \multicolumn{1}{c|}{ Specifications } \\
\hline Pump type & submersible \\
\hline Country of origin & India \\
\hline Manufacturer & Shakti Pumps (1) Ltd. \\
\hline Model & QF100-04ST \\
\hline Pump size & $4 " / 4$ \\
\hline Flow range & $20-70 \mathrm{~m}^{3} / \mathrm{h}$ \\
\hline Head range & $22-52 \mathrm{~m}$ \\
\hline $\begin{array}{l}\text { Rated flow (at total dynamic head } \\
\text { of ..m) }\end{array}$ & $60 \mathrm{~m}^{3}$ \\
\hline Speed & $2900 \mathrm{rpm}$ \\
\hline No. of stages & 4 \\
\hline power required for pump & $7.5 \mathrm{~kW}(10 \mathrm{hp})$ \\
\hline Rated pump efficiency & $75 \%$ \\
\hline & \\
\hline Electric motor & $\mathrm{AC} \mathrm{submersible}$ \\
\hline Motor Type & Shakti- SML-150 [C] \\
\hline Rated power & $7.5 \mathrm{~kW}(10 \mathrm{hp})$ \\
\hline Rated current & $18 \mathrm{~A}$ \\
\hline Rated voltage & $380-415 \mathrm{~V}$ \\
\hline Frequency & $50 \mathrm{~Hz}$ \\
\hline Phase & 3 \\
\hline
\end{tabular}


6- To cover the power losses during operation, $25 \%$ extra power was added to the electric motor power of $7.50 \mathrm{~kW}$, then the required PV power will be $9.375 \approx 10 \mathrm{~kW}$.

7- The specifications of the required PV modules to operate the solar pumping system is described in Table (4).

\section{Table (4): The selected solar PV module}

\begin{tabular}{|l|l|}
\hline \multicolumn{1}{|c|}{ Solar PV module } & \multicolumn{1}{c|}{ Specifications } \\
\hline PV type & Polycrystalline \\
\hline Maximum power & $285 \mathrm{~W}$ \\
\hline Open circuit voltage & $38.7 \mathrm{~V}$ \\
\hline Short circuit current & $9.42 \mathrm{~A}$ \\
\hline Maximum power voltage & $31.7 \mathrm{~V}$ \\
\hline Maximum power current & $9 \mathrm{~A}$ \\
\hline Maximum system voltage & $1000 \mathrm{~V}$ \\
\hline Power tolerance & $0-+3 \%$ \\
\hline Dimensions & $1.640 \times 0.992 \times 0.035 \mathrm{~m}$ \\
\hline
\end{tabular}

8 - The number of PV modules was determining to produce $10 \mathrm{~kW}$ can be determined as:

$$
\text { No. of PV modules }=\frac{\text { Installed PV power }(W)}{\bmod \text { ule Max. power }}=\frac{10000}{285}=35.08 \approx 36 \mathrm{mod} \text { ule }
$$

9- $36 \mathrm{PV}$ modules with total area of $58.567 \mathrm{~m}^{2}$ were installed in arrays at tilt angle of $27^{\circ}$ that nearly equal to the latitude of the experiment's site of $26^{\circ}$ with facing the south direction. The PV arrays were adjusted to be 18 Series $\times 2$ Parallel means the one array including 18 modules and to arrays connected parallel as follows:

- One array Series connection $=18$ module $\times 31.7 \mathrm{~V}=570.6 \mathrm{~V}$ and constant current $=9 \mathrm{~A}$

-2 arrays parallel connection $=9 \times 2=18 \mathrm{~A}$ at constant Voltage $=570.6 \mathrm{~V}$

- The total power of the PV arrays $=$ Current $\times$ Voltage $=18 \times 570.6=10270$ $\mathrm{W} \approx 10 \mathrm{~kW}$

10- AC Variable speed drive (ABB model- $7.5 \mathrm{~kW}$ ) was used to adjust the voltage to frequency ratio to achieve optimum current for pump motor. This minimizes motor losses, noise and the amount of energy drawn by the motor, as shown in Fig.(1). 
Ultimately, the solar PV pumping system was installed as illustrated in Figs.(2) and (3).

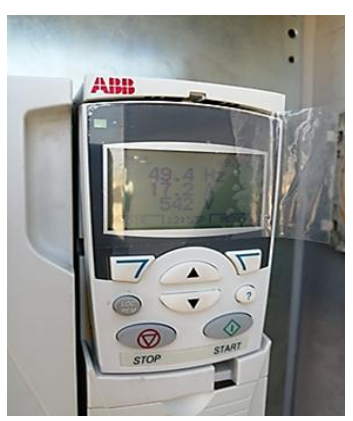

Fig.(1): AC variable speed drive/ low voltage drive

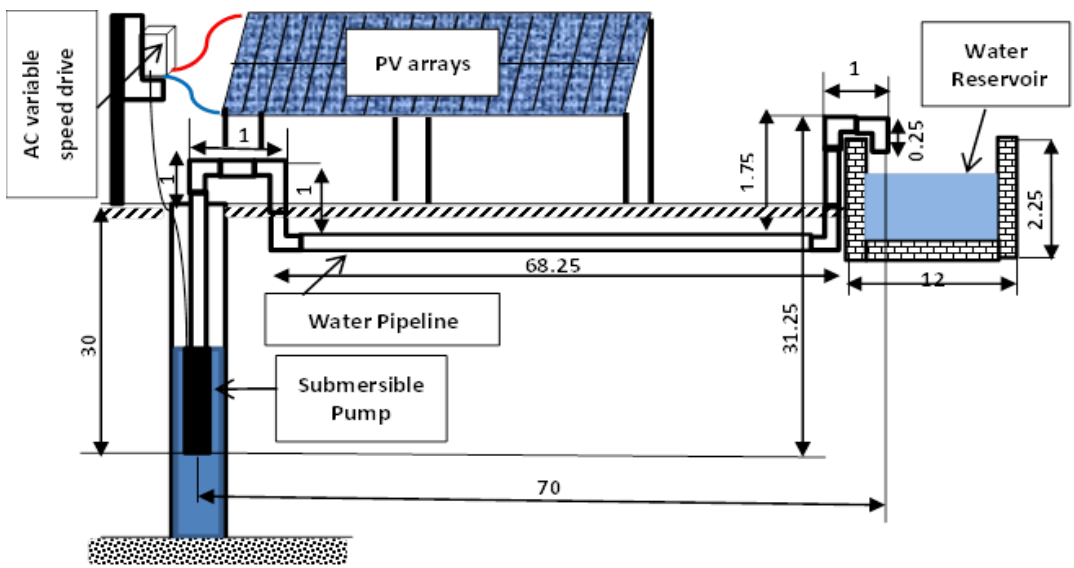

Fig.(2): Schematic layout of the designed solar PV pumping system.
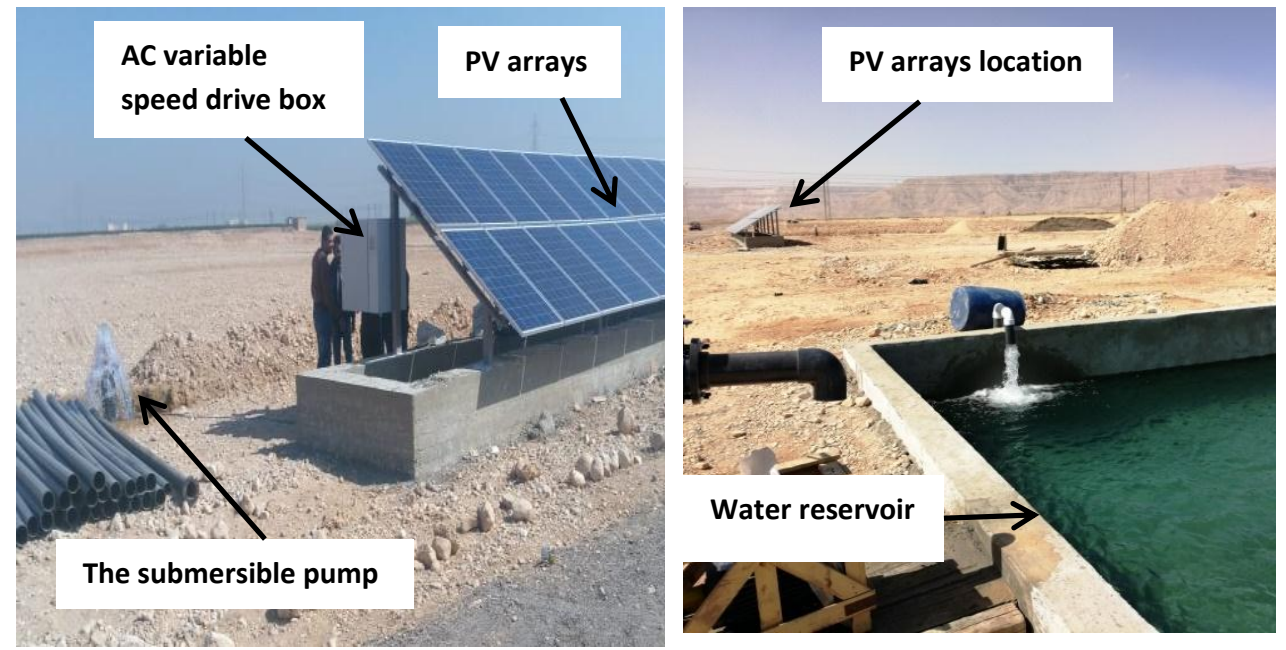

Fig.(3): Photo of the designed solar PV pumping system during the test stage. 


\section{B- Performance assessment of the installed solar pumping system}

The performance of the installed PV pumping system was assessed under the lowest solar radiation intensity taking into consideration the influence of the solar insolation on the hydraulic power and performance indicators including the pump and system efficiencies. The solar radiation intensity was measured by using digital solarimeter (TES-132, TENMARS, Taiwan) with measuring range of $0-2000 \mathrm{~W} / \mathrm{m}^{2}$ and resolution 0.1 $\mathrm{W} / \mathrm{m}^{2}$. The flow rate was determined by using ultrasonic flowmeter (SLF500, USA).

\section{C- Cost analysis}

The LCC analysis was carried out for the solar PV and diesel underground water pumping systems. The whole pumping costs of underground water included the capital cost, operating and maintenance cost, as well as replacement costs including pump replacement after 10 years. Assuming useful life of 20 years (including ten years life for pump) for PV system and 10 years (including one year life for diesel engine starting battery) for diesel system, the capital costs of two systems are given in Table(5) .

\section{Table (5): The capital cost of both solar PV and diesel systems}

\begin{tabular}{|c|c|}
\hline Components of solar PV pumping system & $\begin{array}{c}\text { Cost } \\
(\text { EGP) }\end{array}$ \\
\hline 36(18Sx2P) PV modules (Polycrystalline $285 \mathrm{~W}$ ) & 46480 \\
\hline Driver ABB ACS355/380V- 23.1A - $7.5 \mathrm{KW}$ & 6000 \\
\hline Mounting structure (Galvanized steel chassis) & 8000 \\
\hline $\begin{array}{l}\text { Installation material (PV combiner box include fuses, MCB, SPD, DC-Cable, Earth } \\
\text { connection, and all Accessories) }\end{array}$ & 5000 \\
\hline Installation works including manpower needed to install the system & 3000 \\
\hline Pipeline & 15000 \\
\hline Submersible pump $(7.5 \mathrm{~kW} / 10 \mathrm{hp})$ & 12000 \\
\hline Total capital cost $(\mathrm{CC})$ & 135480 \\
\hline Components of Diesel pumping system & $\begin{array}{c}\text { Cost } \\
(\text { EGP) }\end{array}$ \\
\hline Diesel generator $(10 \mathrm{~kW})$ & 30000 \\
\hline Mounting structure (Galvanized steel with concrete base) & 1000 \\
\hline Battery for diesel motor starting & 2500 \\
\hline Pipe line & 15000 \\
\hline Submersible pump $(7.5 \mathrm{KW})$ & 12000 \\
\hline Total capital cost $(\mathrm{CC})$ & 60500 \\
\hline
\end{tabular}

This cost analysis was estimated in the following LCC analysis according to equations given by Chel et al., (2009): 
-Present operating and maintenance cost

$$
P_{\text {OM }}=C_{\text {OM }}\left[\frac{\left((\mathbf{1}+\mathbf{i})^{\mathbf{n}}-\mathbf{1}\right)}{\left(\mathbf{i} \times(\mathbf{1}+\mathbf{i})^{\mathrm{n}}\right)}\right]
$$

Where:

$\mathrm{P}_{\mathrm{OM}}=$ Present operating, maintenance $\&$ repairs cost (EGP).

$\mathrm{C}_{\mathrm{OM}}=$ Annual operating, maintenance and repairs cost (taken $1 \%$ of capital cost for PV system and $10 \%$ for diesel engine in addition to fuel cost $\left.\left(\mathrm{FC}_{\mathrm{d}}\right)\right)$.

$\mathrm{i}=$ Interest rate (taken $8 \%$ for PV system and $17 \%$ for diesel system, according to The Central Bank of Egypt).

The summation of the yearly consumed fuel costs $\left(\mathrm{FC}_{\mathrm{d}}\right)$ for diesel system was calculated from the following equation. The fuel inflation rate (f) used $12.7 \%$ (The Central Bank of Egypt). Fuel cost assuming the life time of 10 years for the Diesel system is calculated from:

$$
\mathrm{FC}_{\mathrm{d}}=\mathrm{C}_{\mathrm{F}}\left[\left(\frac{1+\mathbf{f}}{\mathbf{i}+\mathbf{f}}\right) \times\left(1-\left(\frac{1+\mathbf{f}}{1+\mathrm{i}}\right)^{10}\right)\right]
$$

\section{$\underline{- \text { Net present cost }}$}

$$
\begin{aligned}
& \mathrm{P}(\text { Net })_{\mathrm{PV}}=\mathrm{CC}+\left[\mathrm{C}_{\mathrm{OM}}\left[\frac{\left((1+\mathrm{i})^{20}-1\right)}{\left(\mathrm{i} \times(1+\mathrm{i})^{20}\right)}\right]\right]+\left[\frac{\mathrm{C}_{\mathrm{P}}}{(1+\mathrm{i})^{10}}\right]-\left[\frac{S_{P V}}{(1+\mathrm{i})^{20}}\right] \\
& \mathrm{P}(\text { Net })_{\mathrm{d}}=\mathrm{CC}+\mathrm{FC}_{\mathrm{d}}+\left[\mathrm{C}_{\mathrm{OM}}\left[\frac{\left((1+\mathrm{i})^{10}-1\right)}{\left(\mathrm{i} \times(1+\mathrm{i})^{10}\right)}\right]\right]+\left[\frac{\mathrm{C}_{\mathrm{b}}}{(1+\mathrm{i})^{1}}\right]-\left[\frac{S_{d}}{(1+\mathrm{i})^{10}}\right]
\end{aligned}
$$

Where:

$\mathrm{P}(\mathrm{Net})=$ Net present cost $(\mathrm{EGP})$.

$\mathrm{CC}=$ Capital cost $(\mathrm{EGP})$.

$\mathrm{C}_{\mathrm{P}}=$ Pump replacement cost $(\mathrm{EGP})$.

$\mathrm{C}_{b}=$ Battery replacement cost (EGP).

$\mathrm{S}=$ Salvage value of system at the end life time (taken $15 \%$ of capital cost for PV system and 20\% for diesel system) (EGP).

\section{-Annualized cost}

$$
\mathbf{A}_{\mathbf{A}}=\mathbf{P}_{\mathrm{Net}}\left[\frac{\left(\mathbf{i} \times(\mathbf{1}+\mathbf{i})^{\mathbf{n}}\right)}{\left((\mathbf{1}+\mathbf{i})^{\mathbf{n}}-\mathbf{1}\right)}\right]
$$

Where:

$\mathrm{A}_{\mathrm{A}}=$ Annualized cost of system (EGP/year).

$\mathrm{n}=20$ years for PV system and 10 years for diesel system. 


\section{- Cost per volumetric unit of pumping}

The cost of pumping one cubic meter of water by two systems was calculated in $\mathrm{EGP} / \mathrm{m}^{3}$, as the following equation:

$$
\mathbf{C}_{\mathrm{V}}=\frac{\mathbf{A}_{\mathbf{A}}}{\mathbf{V}_{\mathbf{W}}}
$$

Where:

$\mathrm{V}_{\mathrm{W}}=$ total annual volume of pumping water for the two systems $\left(\mathrm{m}^{3} /\right.$ year) based on 6h/day of pumping.

All the parameters used in the LCC method is showed in Table (6) below.

Table (6): The used parameters in LCC method for the PV and diesel pumping systems

\begin{tabular}{|l|c|c|}
\hline \multicolumn{1}{|c|}{ Parameters } & $\begin{array}{c}\text { PV system } \\
(\mathbf{1 0 k W )}\end{array}$ & $\begin{array}{c}\text { Diesel system } \\
(\mathbf{1 0 k W )})\end{array}$ \\
\hline Interest rate (\%) & 8 & 17 \\
\hline Life time of system (year) & 20 & 10 \\
\hline Life time of pump (year) & 10 & 10 \\
\hline Salvage (\%) & 15 & 20 \\
\hline Inflation rate (\%) & - & 12.7 \\
\hline $\begin{array}{l}\text { Operation and maintenance costs } \\
\text { (\% of capital cost) }\end{array}$ & 1 & 10 \\
\hline
\end{tabular}

\section{RESULTS AND DISCUSSION}

\section{1- The variation of solar radiation}

The variation of the average values of the hourly incident solar radiation intensity throughout the assessment period that extended for five consecutive days under the winter climatic conditions at the experimental site is depicted in Fig.(4). The practical measurement revealed that the solar radiation intensity was very weak before 9:00 am and rapid declination of the intensity after time of 15:00. Thus, the values of the average hourly solar radiation intensity are plotted in-between the mentioned hours. During the assessment period, the average hourly solar radiation intensity was increased from $433 \mathrm{~W} / \mathrm{m}^{2}$ to reach its peak value $776 \mathrm{~W} / \mathrm{m}^{2}$ at $12: 30 \mathrm{pm}$, afterwards it tends to decrease gradually to reach $413 \mathrm{~W} / \mathrm{m} 2$ with average value of $551 \mathrm{~W} / \mathrm{m}^{2}$ within 6 hours only. It is clear the solar insolation hours concentrated within the 6 hours that represents the daily peak energy and it is agreed with the suggested sunny hour's number in the design procedure of the solar PV pumping system. 


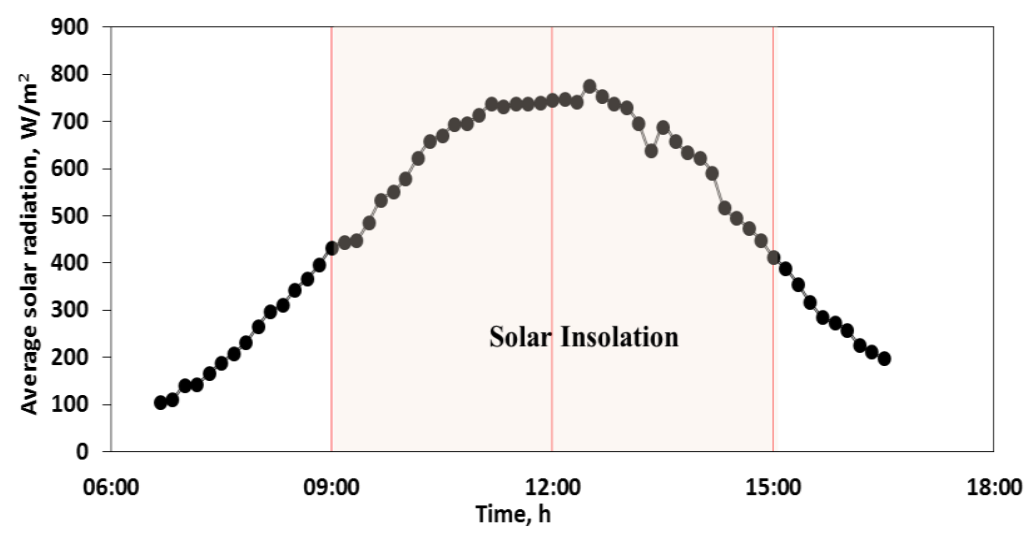

Fig.(4): Average hourly solar radiation intensity during the five days of the assessment period.

\section{2- The behavior of the electric current and voltage produced by the PV arrays}

The DC electric current and voltage produced by the installed PV arrays according to the optimum configuration of 18 Series $\times 2$ Parallel gave the maximum current of $18 \mathrm{~A}$ and maximum voltage of $570.6 \mathrm{~V}$. The high voltage of the $\mathrm{PV}$ arrays was adapted by $\mathrm{AC}$ variable speed drive to low voltage of $380 \mathrm{~V}$ to meet the required voltage of the submersible electric motor and prevent the motor from damage due to the shock that can be expected by the fast variation of the current. Fig.(5) shows the characteristics of the average values of measured PV current and voltage by the AC low voltage drive. The obtained data indicated to clear variation in current value, where it was at its lowest average value of 11.50 $\mathrm{A}$ at 9:00 and increased till its highest average value of 17.5 $\mathrm{A}$ at 12:50,then declination trend was observed after that. It clear that variation of the values of the produced current took the same trend of the daily solar radiation intensity distribution with average value of $16 \mathrm{~A}$, and this means the solar radiation affect strongly the electric current of PV arrays. Simultaneously, the PV voltage remained stable at average values of $547.5 \mathrm{~V}$ and below the designed voltage of 570 regardless the variation of solar radiation intensity. Hence, the values of the produced current and voltage during the assessment stage were very close to the calculated values in the design of the PV pumping system. 


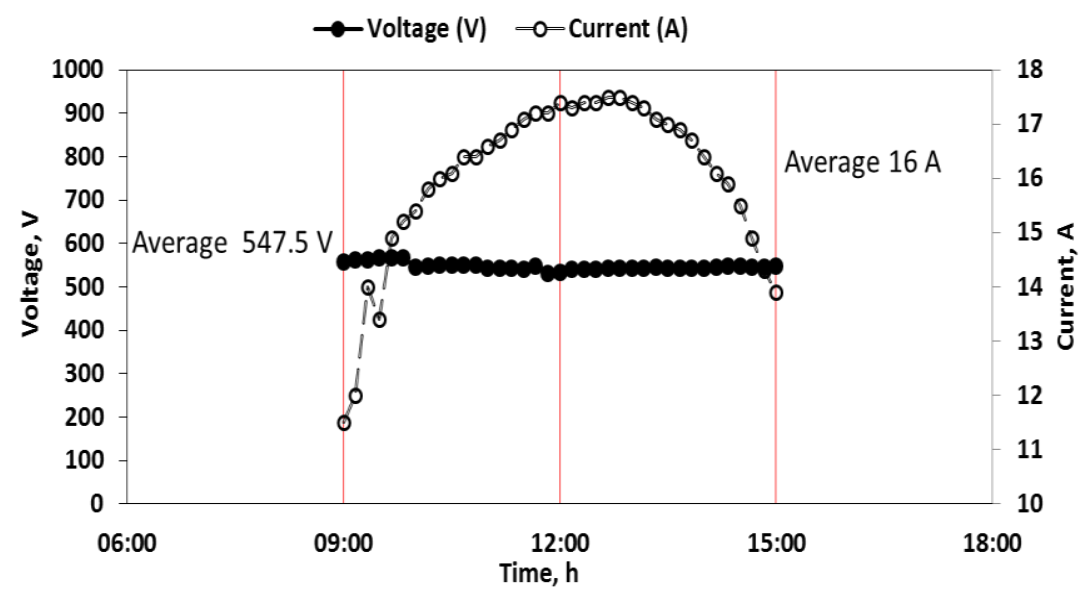

Fig.(5): Variations of the current and voltage produced by PV over the solar insolation hours during the assessment period

\section{3- Variation of the pump flow rate over the time of day and solar radiation}

Fig.(6) shows the relation between the pump flow rate and the times of the day, particularly during the solar insolation period that extended from 9:00 to 15:00 which considered the core period of the solar energy at the site of this investigation. The recorded values of the water flow rate indicated that the average flow rate was increased from $32.2 \mathrm{~m}^{3} / \mathrm{h}$ at the start of the insolation period to its peak value of $60 \mathrm{~m}^{3} / \mathrm{h}$, then the flow rate tends to decrease gradually at afternoon period to considerable flow rate of $37.2 \mathrm{~m}^{3} / \mathrm{h}$ with an average daily flow rate $49.50 \mathrm{~m}^{3} / \mathrm{h}$. This means that the solar PV pumping system gave higher flow rate than the design flow rate of $48 \mathrm{~m}^{3} / \mathrm{h}$, hence the assessment proved high validation of the design aspects. Fig.(7) depicts the relation between the average pump flow rate and the average solar radiation intensity, during the solar insolation period. The obtained data proved a high correlation of $\mathrm{R}^{2}=0.9618$ between the water flow rate and the incident solar radiation onto the PV arrays and the linear equation of $y=0.0741 x+3.8795$ that depicted in Fig.(7).This equation can be used to prospect the flow rate at any solar radiation within the insolation period of the site. It is obvious that solar radiation intensity has major influence on the water flow rate due to the variation occurred in the electric current. High validation of the assessment results with the design aspects of the PV pumping system was achieved. 


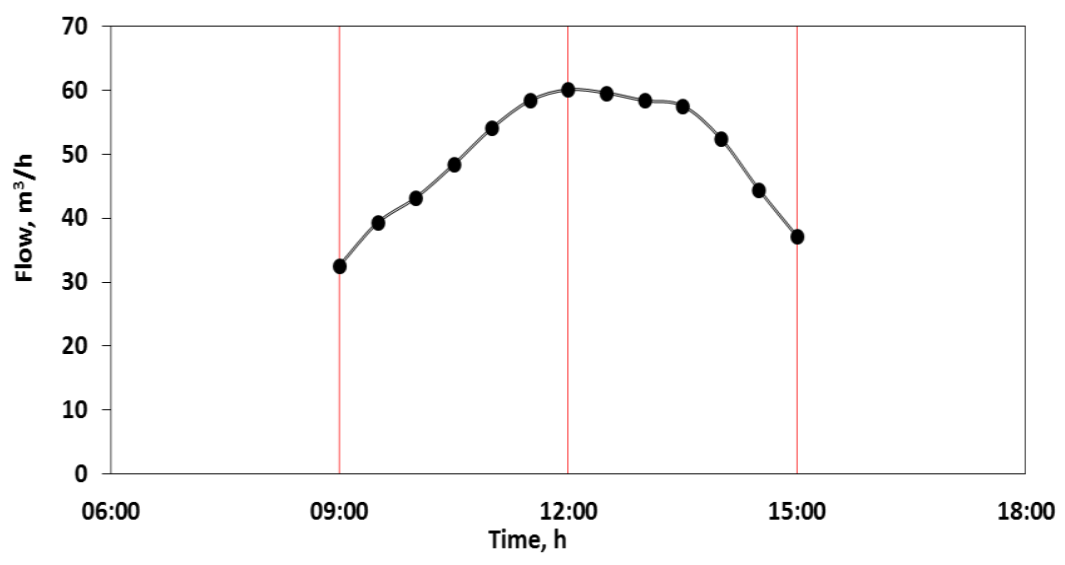

Fig.(6): Relation between the pump flow rate and the times of the day during the solar insolation period

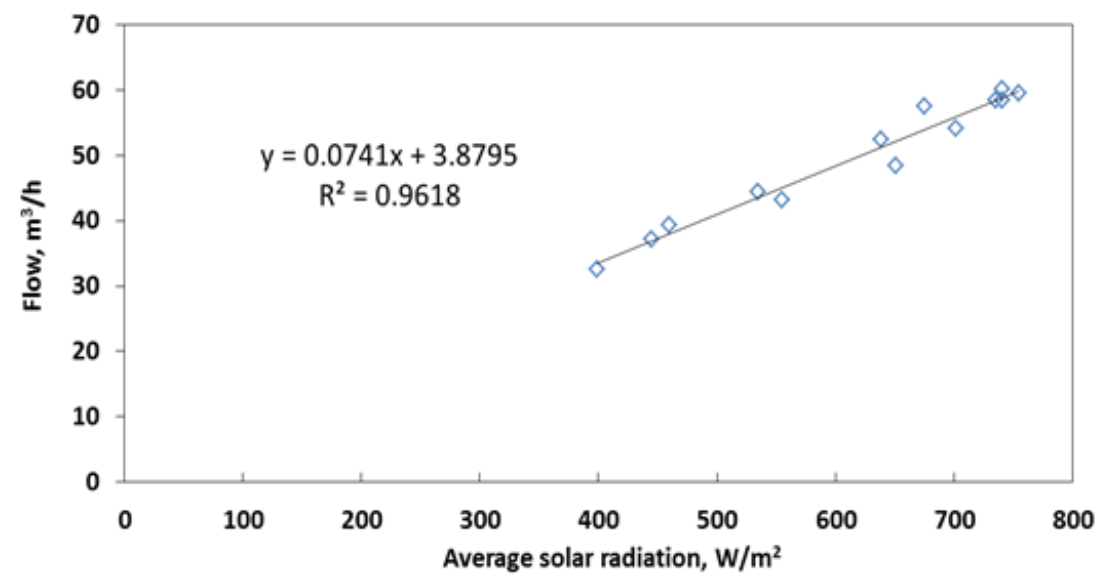

Fig.(7): Relation between the pump flow rate and average solar radiation intensity during the solar insolation period.

\section{4- The generated power within the solar PV pumping system}

Fig.(8) illustrates the variation of submersible pump hydraulic power and the electric power generated by the PV arrays with the time of day during the solar insolation period. The obtained data showed that the pump hydraulic power was varied obviously during the insolation period. This can be attributed to the variation occurred in the electric current and consequently the water discharge due to the variation of the solar radiation. The obtained data showed that the maximum hydraulic pump power was $7518.40 \mathrm{~W}$ at 12:00 (the noon) which is higher than the designed hydraulic power of $7394.5 \mathrm{~W}$. This means that the pump 
efficiency was exceed the suggested efficiency of $75 \%$ during sizing the PV pumping system and the selected pump has a good performance. On the other hand, the electric power generated by the PV arrays depends on the produced current. Since the current affected strongly by the solar radiation intensity, the electric power will be influenced indeed, as depicted in Fig.(8). The data showed that the average pump hydraulic power and electric power of 5720.14 and $8738.7 \mathrm{~W}$, respectively.

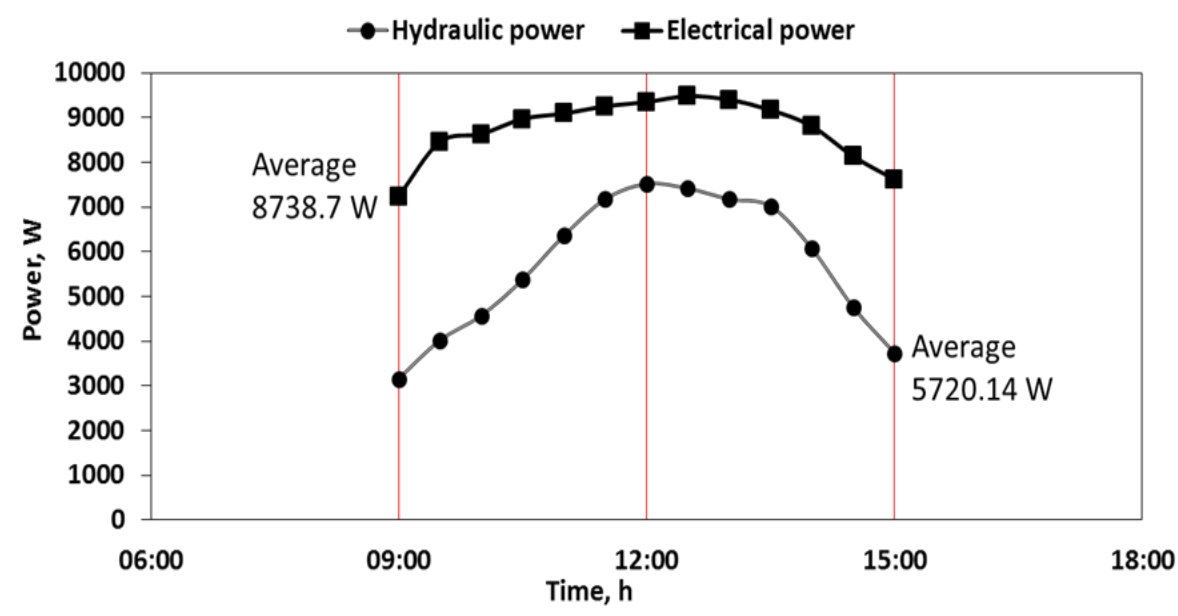

Fig.(8): The hydraulic power of the submersible pump and electric power of the PV during the solar insolation period.

\section{5- The pump and solar PV pumping system efficiencies}

Fig.(9) displays the submersible pump and the PV pumping system efficiencies with the time of day during the solar insolation period. It is known that pump efficiency resulted through dividing the hydraulic power by the generated output electric power that greatly influenced by solar radiation which is make an obvious variations in current, speed of pump motor and consequently the water discharge as well as the pipeline friction losses. The obtained results showed that the pump efficiency increased from $43.60 \%$ at 9:00 and tends to increase to reach the maximum efficiency of $80 \%$ which is exceeded the design pump efficiency of $75 \%$ at noon then it retarded to reach $49.10 \%$ at 15:00 with average efficiency of $64.80 \%$.This variation due to the effect of solar radiation on the PV current which made the motor speed unstable and consequently the hydraulic power, but there is no doubt that the selected 
pump has potential performance. The efficiency of solar PV pumping system is the mirror of PV capability to convert the maximum amount of solar energy to electric power then to hydraulic power. The system efficiency increased from $11.30 \%$ at 9:00 and tends to increase to reach the maximum efficiency of $14.50 \%$ at $12: 00$, then it declined to reach 12 $\%$ at 15:00 with average daily efficiency of $13.10 \%$.

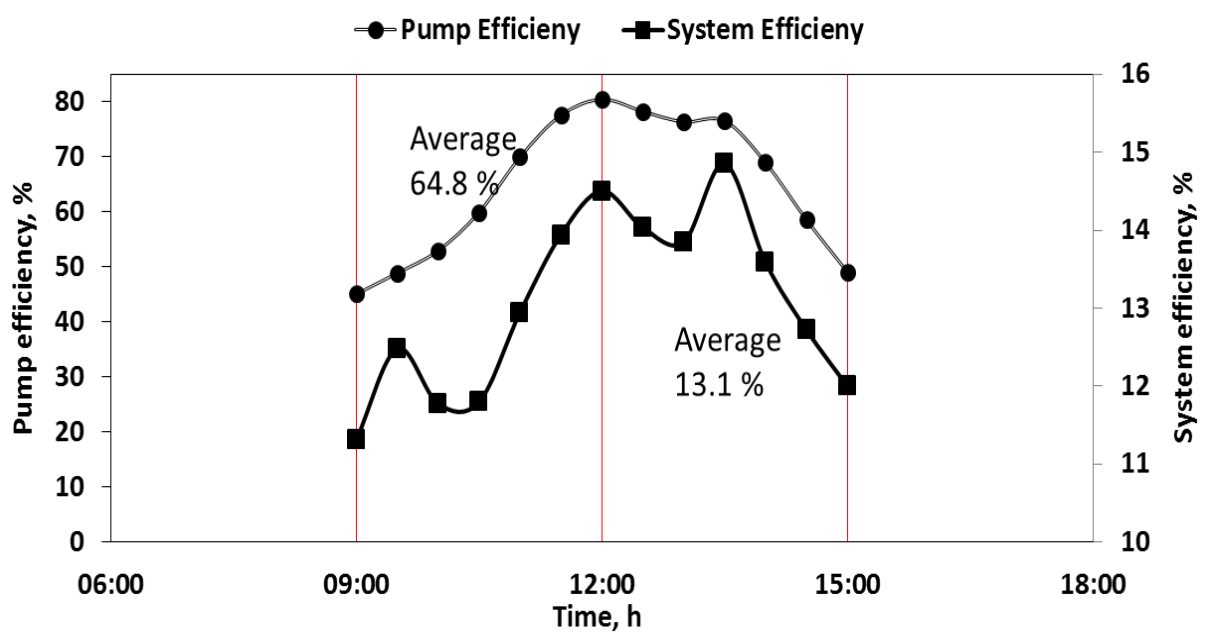

Fig.(9): The pump and solar PV pumping system during the solar insolation period.

\section{6- The cost analysis}

The life cycle cost (LCC) was used to estimate the cost per volumetric unit of water pumping by the designed solar PV pumping system comparing to cost per volumetric unit of water pumping using dieselpumping system, with noting that the common pumping system at the location of investigation depends on diesel for generating electricity due to the poor connection to the national grid. Fig.(10) depicts the actual costs of both systems that used in the cost analysis, where the annualized total cost of PV solar pumping system and diesel-pumping system were 15275.78 and 29005.95 EGP, respectively with advantage of saving cost for the PV pumping system with about $47.33 \%$. This can be attributed to the high actual (not subsidized) cost of the diesel fuel at the long run on the level of increasing the fuel price, transporting and problem related to the availability. 


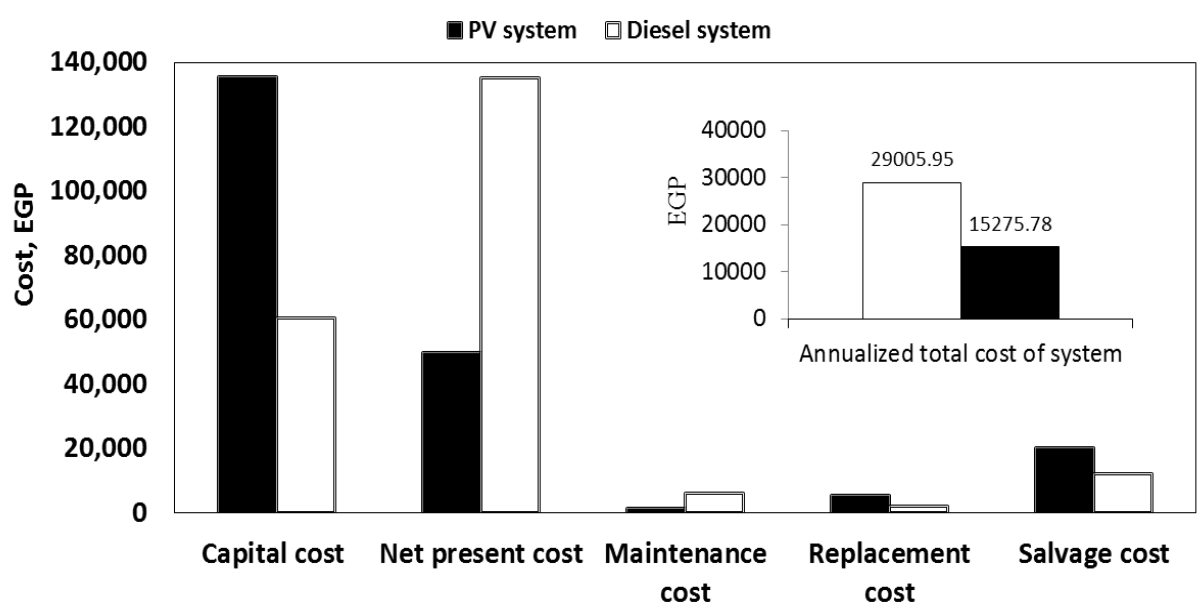

Fig.(10): The costs of PV and diesel pumping systems used in the

\section{LCC method.}

The water pumping criterion cost of the PV solar pumping system represented in the cost per volumetric water pumping was calculated and compared to the diesel pumping system taking into consideration the actual (not subsidized) prices of diesel fuel in year of 2018. The costs calculations based on the LCC method revealed that pumping cost per cubic meter of water were 0.14 and $0.22 \mathrm{EGP} / \mathrm{m}^{3}$ for the PV system and diesel-based system, respectively, as depicted in Fig.(11).Hence the cost of pumping water using the designed solar PV pumping system saved cost with about $36.36 \%$ comparing to the diesel-pumping system that operated at the same well.

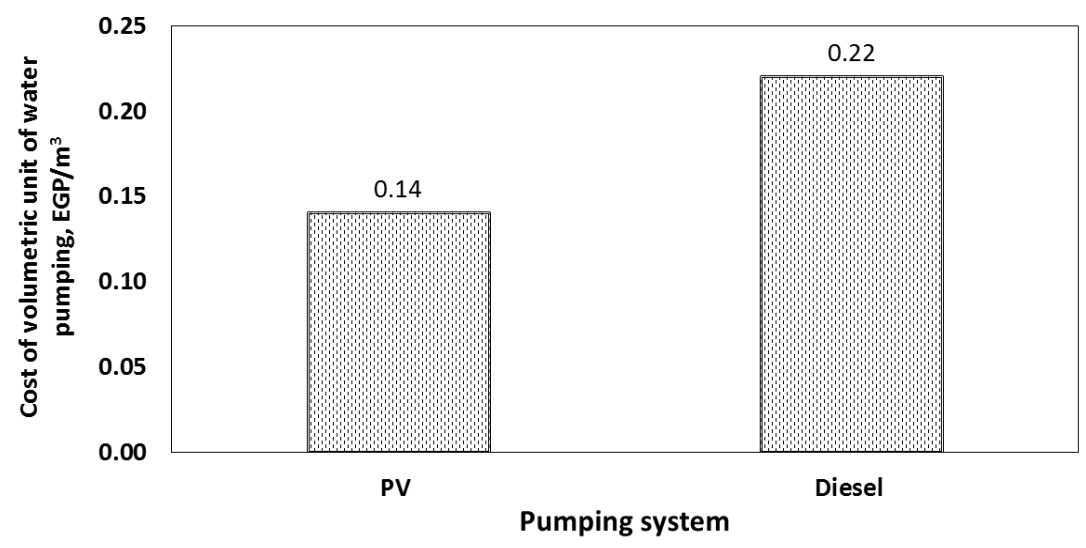

Fig.(11): The cost per cubic meter of pumped water using the solar PV and diesel pumping systems 


\section{CONCLUSION}

This paper presents detailed procedures for designing, assessment of the PV pumping system in winter season at Upper of Egypt. The assessment results indicated to strong effect of the solar radiation intensity on the output PV current and then the submersible motor speed was varied and consequently the hydraulic power of the submersible pump. Considerable efficiencies were achieved to be 64.8 and $13.10 \%$ for pump and the pumping system, respectively. Moreover, the designed solar PV pumping system saved the annualized and pumping costs with about 47.33 and $36.36 \%$, respectively comparing to the diesel-pumping system that operated at the same well. High validation was proved between the design and the actual performance of the PV pumping system

\section{ACKNOWLEDGMENT}

Special thanks and appreciate to ENID/El Nidaa, Cairo, Egypt for Integrated Development and the administrative stuff (in Program C: Sustainable Agricultural Development) to offer the opportunity and facilitate performing experimental researches throughout its own projects for developing villages and communities at Upper Egypt.

\section{REFERENCES}

Aliyu, M., G. Hassan, S. A. Said, M. U. Siddiqui, A. T. Alawami and I. M. Elamin (2018).A review of solar-powered water pumping systems. Renew Sustain Energy Rev., 87:61-76.

Ba, A., E. Aroudam, O. E Chighali, O. Hamdoun and M. L. Mohamed (2018).Performance optimization of the PV pumping system. Procedia Manufacturing, 22: 788-795.

Benghanem, M., K. O. Daffallah, A. A. Joraid, S. N. Alamri and A. Jaber (2013). Performances of solar water pumping system using helical pump for a deep well: A case study for Madinah, Saudi Arabia. Energy Conversion and Management, 65: 50-56.

Chel, A., G. N. Tiwari, and A. Chandr (2009). Sizing and cost estimation methodology for stand-alone residential PV power 
system. International J. of Agile Systems and Management, 4(1-2): 21-40.

Ghoneim, A. A. (2006). Design optimization of photovoltaic powered water pumping systems. Energy conversion and management, 47(11-12): 1449-1463.

Hamidat A. and B. Benyoucef (2009). Systematic procedures for sizing photovoltaic pumping system, using water tank storage. Energy Policy, 37:1489-1501.

Korpale, V. S., D. H. Kokate and S. P. Deshmukh (2016). Performance assessment of solar agricultural water pumping system. Energy Procedia, 90: 518-524.

Li, G., Y. Jin, M. W. Akram and X. Chen (2017). Research and current status of the solar photovoltaic water pumping system-A review. Renew Sustain Energy Rev., 79: 440-458.

Meah, K., S. Fletcher, S. Ula (2008).Solar photovoltaic water pumping for remote locations. Renew Sustain Energy Rev.; 12:472-487.

Munir, A., A.A. Al-Karaghouli and A.A.J. Al-Douri (2007). A PV pumping station for drinking water in a remote residential complex. Desalination, 209:58-63.

REVE (2013). Wind Energy and Electric Vehicle review, Egypt on Solar Energy World Map, Madrid, Spain. https://www.evwind.es

Santra, P., P. C. Pande, A. K. Singh and P. Kumar (2016). Solar PV pumping system for irrigation purpose and its economic comparison with grid-connected electricity and diesel operated pumps. Indian Journal of Economics And Development, 4(4):1-7.

Tawfik, M. A.(2018). Thermal performance of a prototype Quonsetshaped solar cooker. Misr J. Ag. Eng., 35(1):339-358. 
Tiwari, A. K., and V. R. Kalamkar (2018). Effects of total head and solar radiation on the performance of solar water pumping system. Renewable Energy, 118: 919-927.

Ward, D and K. McKague (2007). Water Requirements for Livestock. FactSheet. Ministry of Agriculture, food and rural affairs. Canada. http://www.omafra.gov.on.ca

Zigrang, D.J. and N.D. Sylvester (1982). Explicit approximations to the solution of Colebrook's friction factor equation. AIChE Journal, 28 (3): 514-515.

\section{الملخص العربى}

تصميم وتقييم تشغيل لنظام ضخ للمياه الجوفية تعمل بطاقة الألواح الكهروضوئية الشمسية في صعيد مصر

$$
\text { وسام السيد عبد الله* و محمد علي توفيق" }
$$

هذة العمل محاولة للإقتر اب من التصميم الأمثل وتقييم يشمل الأداء و الجانب الأقتصادي لنظام

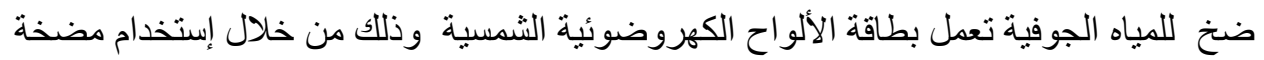

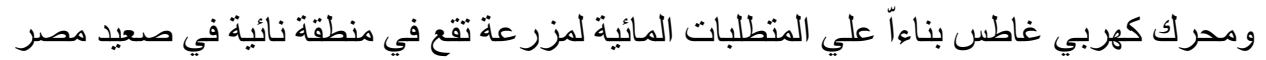

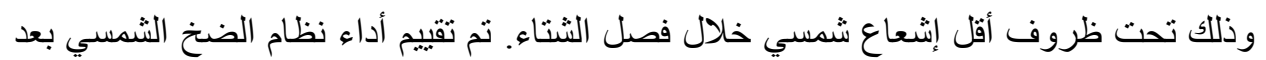

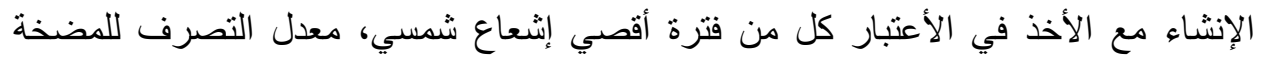

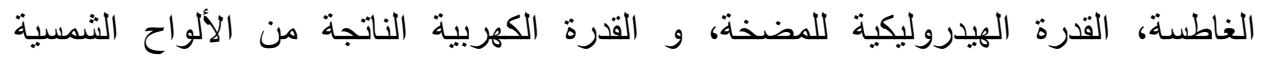

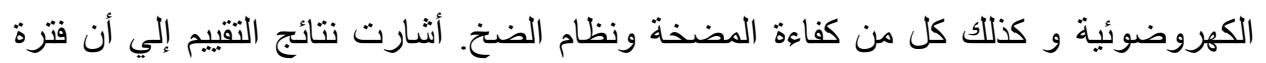

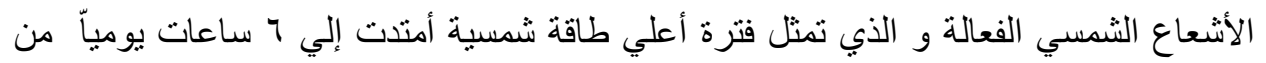

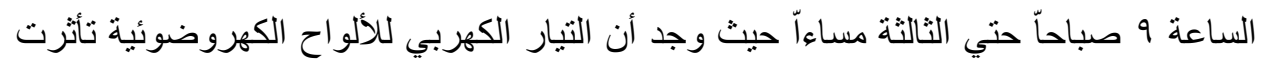

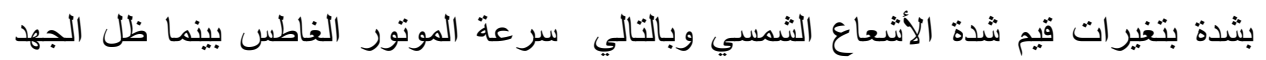

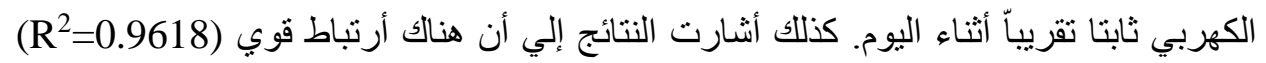

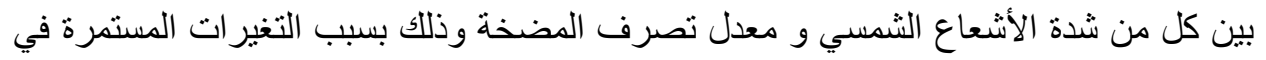

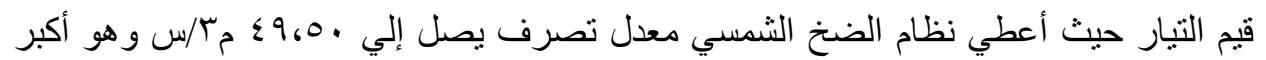

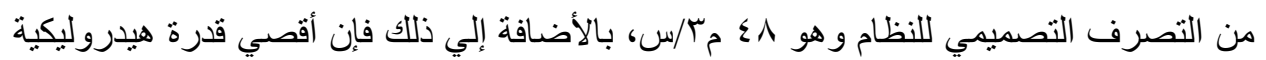

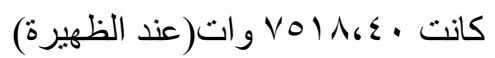

* قسم الهنسة الزراعية ـ كلية الزراعة ـ جامعة الزقازيق - مصر 


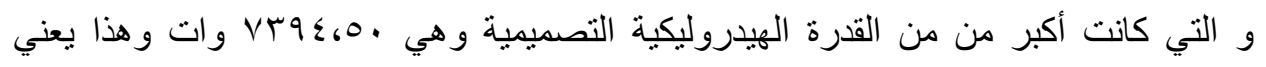

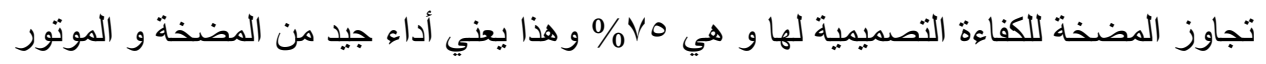

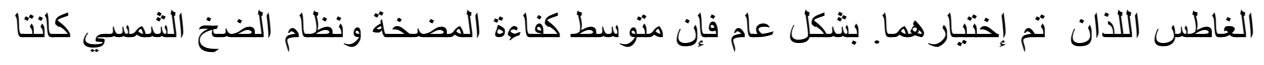

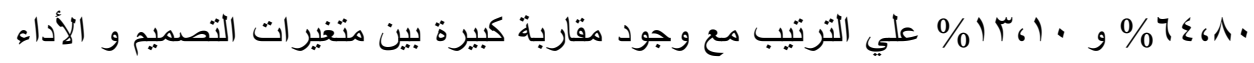

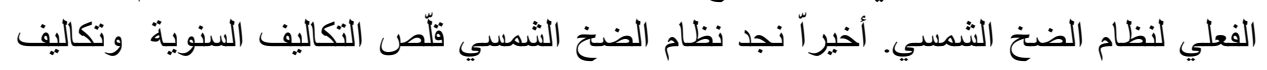

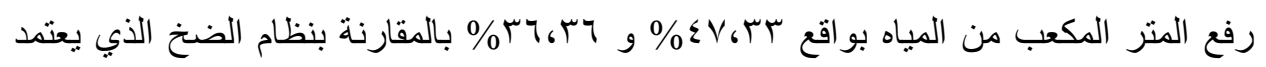
علي محرك الديزل و الذي تم إستخدامه علي نفس البئر. 